\title{
Australia Cost and Benefit in Achieving Climate Commitment 2015-2019
}

\author{
Muhammad Fahrul Risky ${ }^{1,}{ }^{*}$, Imam Mahdi ${ }^{1}$, Angga Misbahuddin $^{2}$, Ilham Agustian Candra ${ }^{1}$ \\ 1 International Program of International Relations, Faculty of Social and Political Sciences, \\ Universitas Muhammadiyah Yogyakarta, Indonesia, 55183 \\ ${ }^{2}$ International Program of Government Affairs and Administration, Universitas Muhammadiyah \\ Yogyakarta, Indonesia, 55183
}

\begin{abstract}
Australia has been one of the majority countries in the world which has committed to the Paris Agreement and has implemented it to cut their emission. Climate change is a tremendous challenge for human being for the past 20 years, since the development of technology and the growing needs of human has driven us to find more source to fulfil our needs. Australia has agreed to cut their emission for $26-28 \%$ that is envisioned to be realized in 2030. However, the Australia's commitment becomes questionable since the massive approval of Liquified Natural Gas in 2016. Experts claim the approval of Liquified Natural Gas will disturb the steady graph emission of Australia. This study aims to find out and analyze the reason behind Australia massive approval to Liquified Natural Gas Project. This study is qualitative research using descriptive analysis method with secondary data types. The result of study shows that, the reason behind the massive approval of Liquified Natural Gas in Australia are to increase and boost up the economy for Australia while at same time open a wider job opportunities for its people.
\end{abstract}

\section{Introduction}

By 2013 the human population has reached for about over 7 billion, this has become clear to the world's scientific that the increasing rate production of carbon dioxide (CO2), Methane and other greenhouse gases in the atmosphere. As a result of rapid increasing agriculture, land use, the transportation processing and everything we were consuming that resulted to the greenhouse gasses was responsible for the climate change. Surely, among the biggest human threat, ecological annihilation and natural destruction is count as one of the biggest threat in human history.

The massive development has had always been one of the key factors to the extremely ambiguous changes on climate change that will affect from the most basic element of living for ecosystem to it's most complicated - start form the uncertainty of food security, the extremely hazardous weather up to the threat of globally epidemic diseases [1]. It is undeniable fact that human has accused for an increase of atmospheric carbon dioxide for

*Corresponding author: mahdi@umy.ac.id 
more than $30 \%$ in a past few centuries - climatologist agree that this caused by the human activity such as the fossil fuels burning, deforestation, industrial activities, and animal husbandry have also contribute to the greenhouse gas increasing since 1800. The greenhouse effect is what the scientist called is warming the Earth land surface below water temperature and it is the result of the extreme amount of carbon trapped in the atmosphere. Environmental issue began to be highlighted by EU and US in 2005.

The creation of key output in addressing the climate change issue is inevitable, especially if we are maintaining to live sustainability without harming the environmental and yet using it as a tool to survive. The scientific proof brought up by the Intergovernmental Panel on Climate Change assessment report in 1990 has revealed the seriousness of climate change as a topic deserving attention through political platform among countries. The global has finally realized the importance of preserving environment although the chairperson Gro Harlem Brundtland of 1982 World Commission and Development argued that development is everything what we need to improve our within and at the same time Brundtland also argued that environment is where we live. Sustainable development defined as the ability to develop in the current time of living by many means including the use of the existing resources yet, without harming the future own needs [2]. Therefore the point idea of sustainable development is introduced in World Summit on sustainable development in 2002 as a goal and mission for national institution, international organization and locals.

The idea of sustainable development was continued to discuss in June 2012 in order to improve it's effectiveness, the world leaders alongside with the representative from the nongovernmental organization and private sector came and sit in line to discuss "the future we want" at the Rio +20 United Conference on sustainable development. The discussion outcome were the extension of the previous development goals which expire in late 2015, afterwards the termed of Sustainable Development Goals alongside with its agenda were introduced that are develop effective, accountable, transparent institution at all levels, ensure responsive, inclusive, participatory and representative decision-making at all levels, and implemented by open e-government [3]. World leaders has come into a sense common commitment which encompass a broad agenda that has written as 17 Goals under the SDG's and one of them is the Climate Action as well set as number thirteen in SDG's agenda.

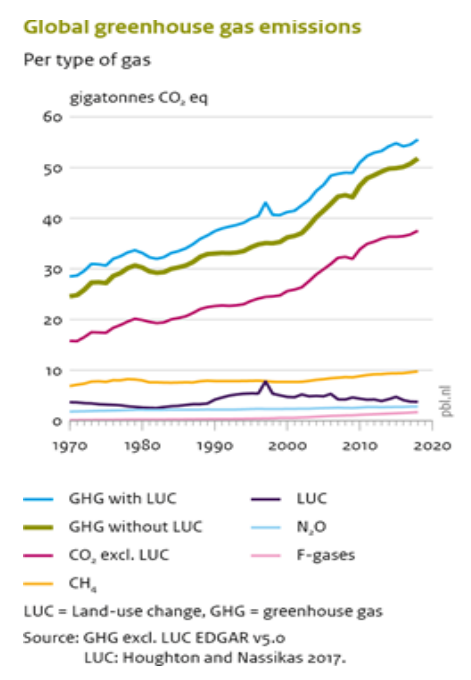

Fig. 1. Global greenhouse gas emissions from all resources from 1970-2018

Source: [4] 
In streamlining the point idea of sustainable development by mitigating the impacts of climate change, the three primary greenhouse gas which consist of carbon dioxide, methane gas and ozone should be taken measure of. As referred form the graphic above, since 1970, the increasing of GHG's is extremely undeniable due to manmade doing. In 2018 the global growth of greenhouse gas has reached 51.8 gigatonnes. The 2018 increasing greenhouse gas was mainly due to an increase in global fossil carbon dioxide $\left(\mathrm{CO}_{2}\right)$ emissions from fossil fuel process and industrial consumption - the annual greenhouse gas growth in 2018 is $2.0 \%$ and it was twice high as expected since 2012, whereseas the average greenhouse gas emission growth is only expected for $1.0 \%$ increase each year [4].

Climate change issue is an extreme threat for every country, the unpredicted change has simultaneously happened to be shocking the whole world and it needs a quick action plan in order to address the issue while living in sustainable. In accordance with the $4^{\text {th }}$ IPCC report in 2007 the increasing of Greenhouse gasses since 1970 has extremely affecting the arctic condition and this will led in to the increasing of sea level 1-8 feet by 2100 . It needs a sufficient whole world cooperation yet efficient to answer the climate change challenge and be prepared for what's coming next. Therefore, every country efforts is count. In this case Australia officials has righteously convince the world that the land of kangaroo is vocal enough in combating the climate change that threatening the world. In 2015 Paris Agreement is introduced, as one of its member parties in this international commitment, Australia has shown to the international community that they are ready to reach $26-28 \%$ of their emission cut by 2030. The entered into force of Paris Agreement is a big momentum for Australia Official Government in fighting the threat of climate change - Australia has committed on spending for at least $\$ 1$ billion in climate development assistance for developing countries from 2015-2020. In addition to its commitment Australia Officials also pledged $\$ 500$ million over 5 years from 2020 to help the Pacific nations invest in renewable energy and climate and disaster resilience. Australia official government in 2013 has designed a trade carbon scheme which will be contributes for its carbon emission cut Australia carbon pricing scheme is an innovative yet one of the best design that had established throughout the history [5].

On the other hand Australia country action at some point is not accordance with the statement that given by the Australia Officials. Australia can be both a hero and yet villain also to its own climate commitment at the same time. In 2015 the government analysis identified the core issue why does Australia's GHG's emissions is still risen due to its LNG activities and project. Liquified Natural Gas is a new attracting way of clean energy due to its low carbon dioxide emission and its simple transportation. It is to be believed that LNG project will lead into a steady demands in a few more decades ahead in future [6].

Australia's officials through its Energy Minister claimed the LNG project should be proud of due to the exchanging place for a massive use of coal power in Australia and this is where the major turn happened [6]. Wheatstone's, Ichtys and Prelude LNG export project activities are one of the example of Australia large scale of LNG starting from 2017-2019. Expert from the Global Energy Monitor had warn the Australia's Official of the booming of LNG project due to its carbon emission rise by $0,7 \%$ in 2018 [7]. The LNG exporting project activities involve the construction of massive new facilities with life expectancies of a decades or more [8]. 


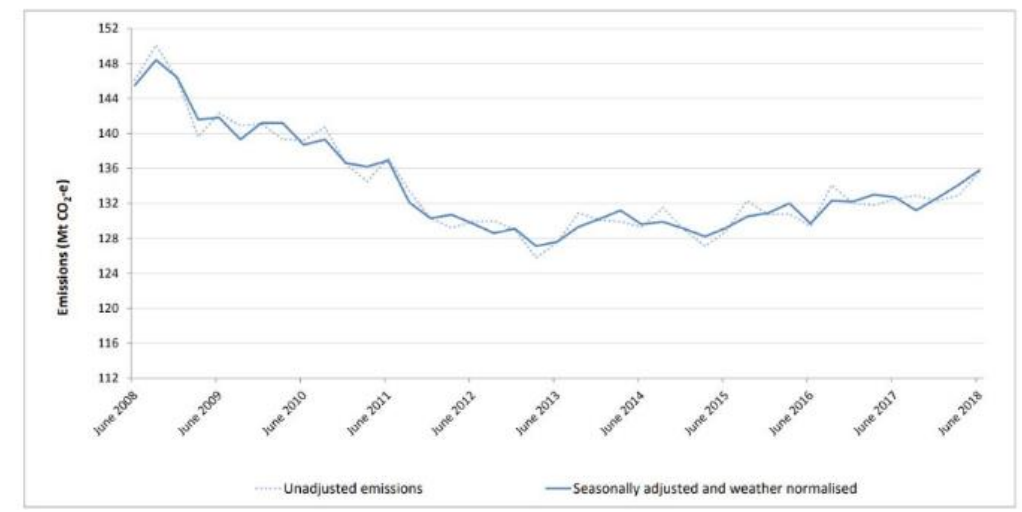

Fig. 2. Australia emissions by quarter 2008 to 2018

In the mid of 2018 Australia's emission had increased for $0,6 \%$ by the previous year. Australia officials through its minister of environment state that the data is still on track to meet Australia's climate commitment to reduce their emission by $26-28 \%$ [9]. Meanwhile Australia's official statement were instantly broke by Dr Joeri Roegelj an expert which main focus is in climate change in the environment in The Grantham Institute for Climate Change, indicating that instead of keeping the climate commitment steady, Australia's official policies shows no evidence for achieving its climate commitment. According to the report LNG export project is mainly responsible for the increasing in June 2018 after a major downturn in March 2018 [10].

By $17^{\text {th }}$ January of 2019 an independent scientific analysis called Climate Action Tracker give an assessment report on how does the Australian government is holding their climate commitment. The report started in the year of 2015 where the Paris agreement were agreed by many countries including Australia. Unsurprisingly, this report from CAT concludes that Australia categorized as a "insufficient", a country with this title is inconsistent and not in line with the Paris Agreement to keep heating below $2^{\circ}$ Celcius, moreover this report also states that "Instead of achieving a commitment to reduce carbon gas emissions by $26-28 \%$ below 2005, the truth revealed that Australia will surpass its commitment by $8 \%$ above gas emissions in 2005" [11]

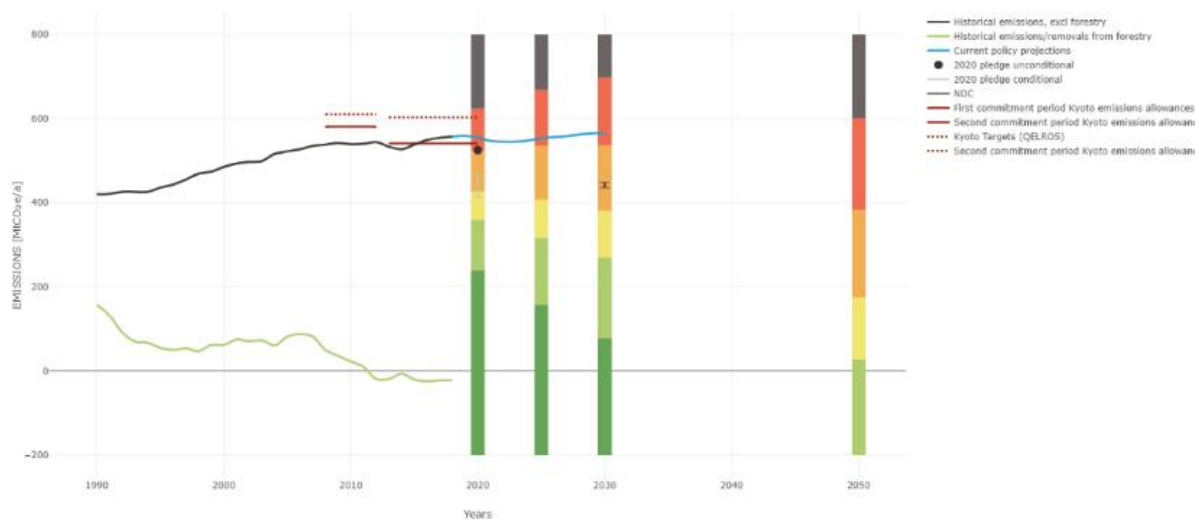

Fig. 3. Climate Action Tracker assessment graph on Australia

Australia's sonorous climate commitment has become questionable throughout 20152019 and contrary to the Sustainable Development Goals agenda number 13. The fallen 
emission on electricity does not affect the increasing of emission carbon which mainly driven by Liquified Natural Gas export project and other industrial process. Moreover, this activity has been warned by the experts about the upcoming unsteady of Australia's climate commitment for $26-28 \%$ by 2030 .

\section{Research Method}

This research use qualitive analysis methodology. The qualitative analysis research divided into five focuses, and the research would use the case study method. The data collection would be from the secondary sources such as; journals, books, reports, official website, and also news. The literature review is from previous research that correlate with the topic [12]. After collecting the data the author would like to use descriptive approach in order to answer the research question by using the theoretical framework.

\section{Result and Discussion}

\subsection{Australia LNG Project}

Oil and gas industry is one of the most promising sectors and is very important for the sustainability of several other sectors. It is projected that there are about 100 million barrels per day used for human activities. Oil and gas industry is also a very profitable sector and often an individual / group or even a country invests in this sector for high long-term financial benefits [13]. The oil and gas industry in Australia is experiencing a very fast development that affects the increase in economic. Australia produces Liquified Natural Gas (LNG), crude oil, and condensate, with this Australia has an important and massive contribution in the supply of oil and gas industry globally- over the past few decades the gross value has increased for Australia.

In fact, the Australia's natural gas reserves are around 30 million cubic feet this means that Australia's natural gas reserves are equivalent to 43.9 times its annual consumption (based on 2015 data Australia's annual consumption is around 1.4 million cubic feet) by this, Australia will be a magnet for investor around the world to have a further exploration for its proven reeves. With the high global demand, the export production of Australian Liquified Natural Gas (LNG) has increased by 3 times, the Australian Liquified Natural Gas (LNG) export production has shifted and replaced Qatar as the largest LNG exporter in the world [14].

At present, with the massive and significant development of technology, natural gas exploration is no longer using the old fashion method which considered risky and expensive. This risk commonly comes because the source of natural gas is usually located far from the coast, therefore using liquefaction is believed to facilitate an easier distribution to the storage, the gas is cooled to $-162^{\circ} \mathrm{C}$ shifting its natural gas form into liquid. This liquefaction process is called Liquified Natural Gas or commonly known as LNG. In 2018 Australia became the country with the second largest LNG export in the world before Qatar based on a report from NS Energy [15]. Australian LNG production continues to increase, in the oil and gas industry LNG ranks second in export commodities after iron ore. The high demand for the use of LNG globally increases significantly, especially in the ASIA region.

The amount of LNG production in Australia is of course influenced by companies running the LNG project starting from 2014 there are 7 major LNG projects that are still under construction, 4 of which will be running in 2015 and 3 of them will begin their exploration above 2015. The LNG project in Australia is located in several parts of 
Australia, in Western Australia there are 4 LNG projects namely Wheatstone, Gorgon, Pluto and NWS while in the Northern Territory there are only 2 LNG projects namely Ichyts and Darwin - as well as the Northern Territory, Queensland there are 2 LNG projects namely Gladstone, APLNG [16].

\subsection{Australia's Environmental consideration of LNG project}

In 2015 there are 4 large LNG projects that will operate on average starting in mid-2016, these projects are Icthys, Gladstone, Prelude and Wheatstone. The Australian government's decision to continue and approve this major LNG project becoming questionable because Australia's carbon emissions commitment is very ambitious. The Australian government's decision received a lot of criticism and protests from environmentalists, they argued that the approval of a major LNG project in Australia was not in line with their climate commitments. In fact, there are several environmental observer communities who have projected the impact of receiving this large LNG project, and Australia is even categorized as "insufficient" (if they still use the current policy) in achieving their climate commitments.

In the construction and production processes of liquified natural gas, there are several effects that the criticism delivered attention to because they affect air quality, wild vegetation, water pollution, and even worse, can be caused an earthquake.

a. Air pollution: Natural gas production is very beneficial for household use, however, apart from these benefits drilling or exploration activities can affect air quality in the area around drilling production. In certain areas there has been an increase in the concentration of air pollutants and between 2 out of 6 can be categorized as "Pollutant Criteria". Exposure to high concentrations of air pollution can cause several symptoms which can lead to deterioration of health, worsening of the respiratory system, cardiovascular and cancer being the worst threat.

b. Wildlife vegetation and land use: The production and construction processes of the Liquified Natural Gas facility require a large area to carry out drilling activities. This process is indicated to cause erosion, damage to the surrounding / local ecosystems and uncertain migration patterns of wild animals. During the land clearing process, pipelines construction and road access this can cause soil erosion to disrupt the surrounding river ecosystem [17]. A study of the impact of hydraulic fracturing in Michigan found the possibility / potential environmental impacts to be significant. Chemical spills, equipment runoff, water table reductions are potential secondary effects of both construction and production of LNG [18].

c. Water use and pollution: The development of construction and production nonconventional oil and natural gas could have an impact on the deterioration of the health quality of the surrounding community through contamination of drinking water sources that have been mixed with dangerous chemicals resulted from the drilling process, the oil and gas refining process, and the residual waste from the process exploration [19].

d. Earthquakes: Hydraulic fracturing is often associated with low-frequency magnitude seismic activity with a force of less than 2.0 SR (unit moment magnitude). Although this seismic activity is classified as low and cannot be felt on the surface, this remains one of the big challenges for natural gas development in future.

\subsection{Environmental Consideration of Australia's Approval in LNG Project Environmental Formulation of Natural Gas Project}

LNG projects in Australia have experienced a very significant increase in several areas of Australia, one of which is the Queensland region. Submitting an LNG project in Australia 
must go through several considerations that have its own parameters - it is aimed to achieve a license as a single integrated operation, for example the Australian government has an Environmental Authority (EA). The Australian central government through the Queensland government carries out the Environmental Authority Relevant (ERA) mechanism activities aimed at assessing and determining the environmental risks / impacts of industrial and agricultural activities that use large areas of land. In Queensland, after applying for the Environmental Authority (EA), it was later continued with Environmental Relevant Activity (ERA).

This activity has been regulated in such a way in the 2019 Environmental Protection Regulation. ERA which received a high risk category assessment is different from ERA which received low risk category score, the relevant authorities use the operational threshold parameter to determine the ERA risk category and the annual costs to be incurred. Apart from obtaining an Environmental Authority (EA) license, all company applications for the production of gas pipelines, main coal seams and liquified natural gas (LNG) projects must go through an assessment and approval process that is schemed by the Australian government and can be considered to be quite strict, this process is called environmental impact statement (EIS). The environmental impact statement is used as a government tool to assess three areas in general, namely to assess the current environmental condition in the area around the project, assess the project's potential environmental, economic and social impacts, and also to avoid / minimize potential adverse impacts from the project.

The EIS mechanism has 6 main objectives for companies to run their oil and gas project, these objectives include: conducting an assessment of potential beneficial and adverse impacts in the affected sector (economic, environmental and social), assessing the actions taken by the related project to minimize the possibility of adverse environmental impacts, conducting consider safe and feasible alternative ways to implement projects, assist national and local governments to make informed decisions, provide information to state authorities, local governments and the public, and assist departments to decide on subsequent approvals [20].

The instrument is meant to see how risky it may appear during the natural gas project's construction and operation phase. Moreover, this mechanism will also categorize those natural project which is considered to be a high risk that could harm the environment will accept more fees annually that the company should pay.

\subsection{Australia Economic Consideration}

It cannot be denied that the government at the provincial and central levels has high revenues due to the promising development and exploration of the oil and gas industry sector. The report on export activities for the period 2018-2019 issued by the Department of Foreign Affairs and Trade (DFAT) shows that every year starting from 2016.

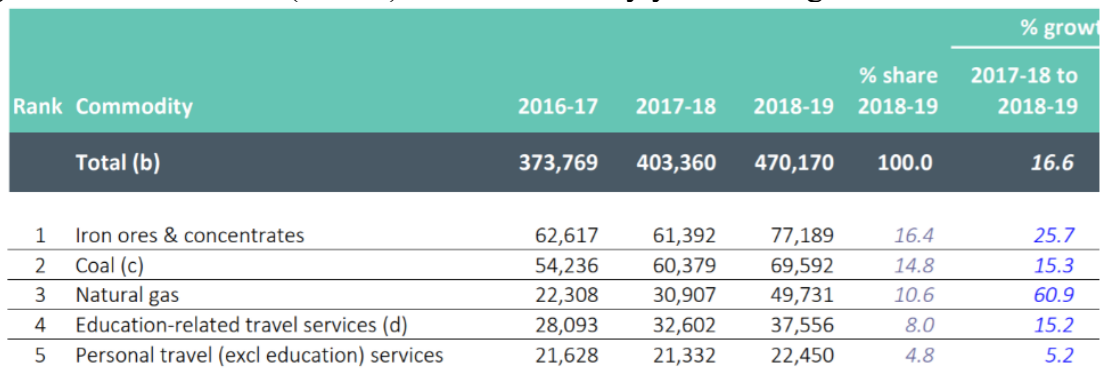

Fig. 4. Australia's top 25 export goods and services (A\$)

Source: [22] 
Australia began to experience an increase investment in the oil and gas industry. Export activities carried out by Australia are dominated by Services, Oil and gas Industry sectors the total export value that Australia received in 2016-2017 reached a total of A\$373.769 billion dominated by oil and gas industry. Later in 2018-2019 Australia has significantly gain more export commodity value compared to 2016-2017 export activity and of course dominated by oil and gas industry, however there was a rapid increasing in natural gas export due to the 9 major LNG projects that were started run in 2015. During the last 5 years natural gas export activities in Australia have increased above other commodities or services with an increase of $23.7 \%$ [21].

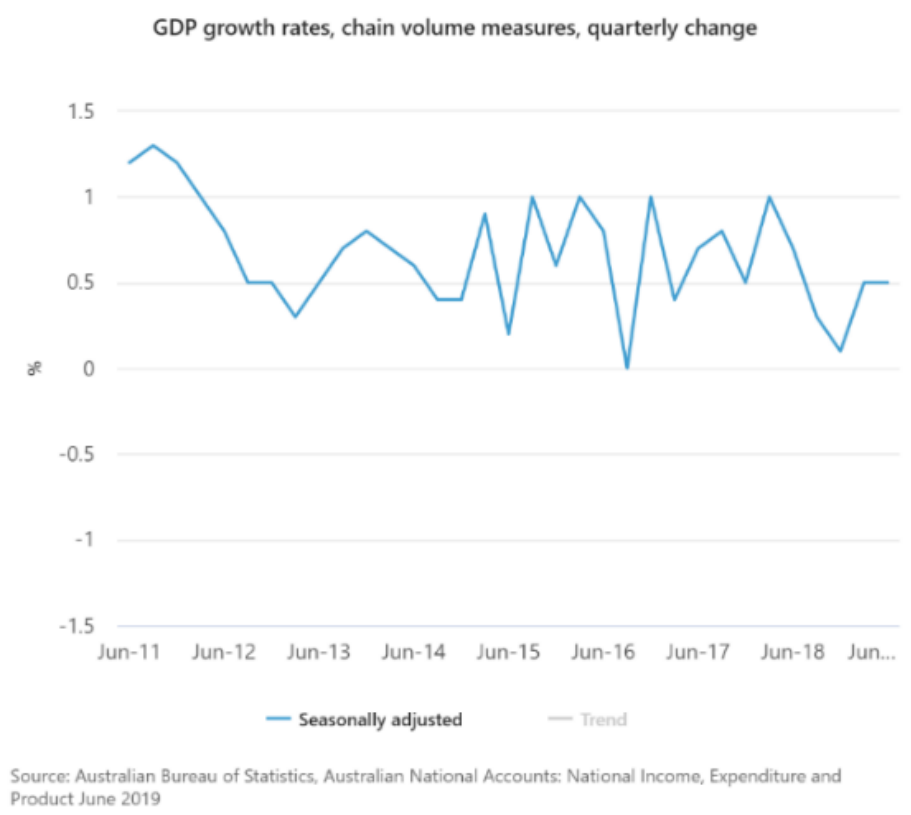

Fig. 5. Australia GDP growth rates seasonally adjusted

The increase in export activities carried out by Australia in the last five years has continued to increase, this certainly affects GDP growth in Australia. In June 2019, Australia's GDP seasonal report increased by a figure of around $\$ 275$ billion, this figure has increased by $0.5 \%$ from the previous season which was valued at $\$ 270$ billion.

Based on a report managed by an independent economic consultant, Acil Allen states that the LNG industry's direct economic impact is extraordinary. It is projected that the Gorgon LNG Project will contribute an estimated \$390 billion to the increase in Australia's GDP in the 2016-2050 period. The Gorgon natural gas project also contributed to the payment of taxes to the government with a total of $\$ 139$ billion in the period between 2016 and 2050, estimated annually to contribute around $\$ 5.4$ billion. This tax will be in the form of corporate tax payments, which will be paid directly to the Australian government due to the production of the Gorgon LNG project natural gas.

On the other hand, the Wheatstone LNG project is projected to last for the next 25 years. In this way, the Wheatstone LNG project will contribute around $\$ 134$ billion between 2016 and 2050. The Wheatstone LNG project aims to contribute around \$ 432 billion between 2016 and 2050 with an average annual tax payment of $\$ 2.1$ billion. This tax payment is obtained from the Wheatstone LNG project's production, which will later be given to the Australian government [22]. 
Prelude Floating Liquified Natural Gas project is an FLNG project which started operation in mid-2017. As with other projects, the prelude is one of the FLNG projects that will benefit Australia in the future. Shell confirmed that the FLNG project would contribute about \$ 11 billion over the Prelude project's life. The General Manager of Production Shell said that this project would contribute $\$ 41.3$ billion to improving the Australian economy [23].

\subsection{Employment Consideration}

The construction of the LNG Project greatly affects the Australian economy and the jobs that will be created in the process going forward. There are 2 phases in LNG construction, the first phase is the construction phase of the $L N G$ project facility and the second phase is the operation of the LNG project. In the first phase of the construction LNG facility, this will affect the prospect job opportunities that will open, starting from short-term jobs to medium-term jobs. In the second phase, the operation of the LNG project requires longterm workers with high skills, during the 2 phases above the LNG sector will create at least around 10,000 workers. This total of 10,000 job opportunities will be filled by several divisions, namely production, operation and maintenance of LNG facilities.

With a total of approximately 7,000 jobs open in one LNG train, it is projected that business partners and company partners will add around 5,000 to 8,000 jobs at the head office to function as managerial and technical to support underwater development. Moreover, to support this activity, the local service sector needs to add about 25,000 to 30,000 jobs.

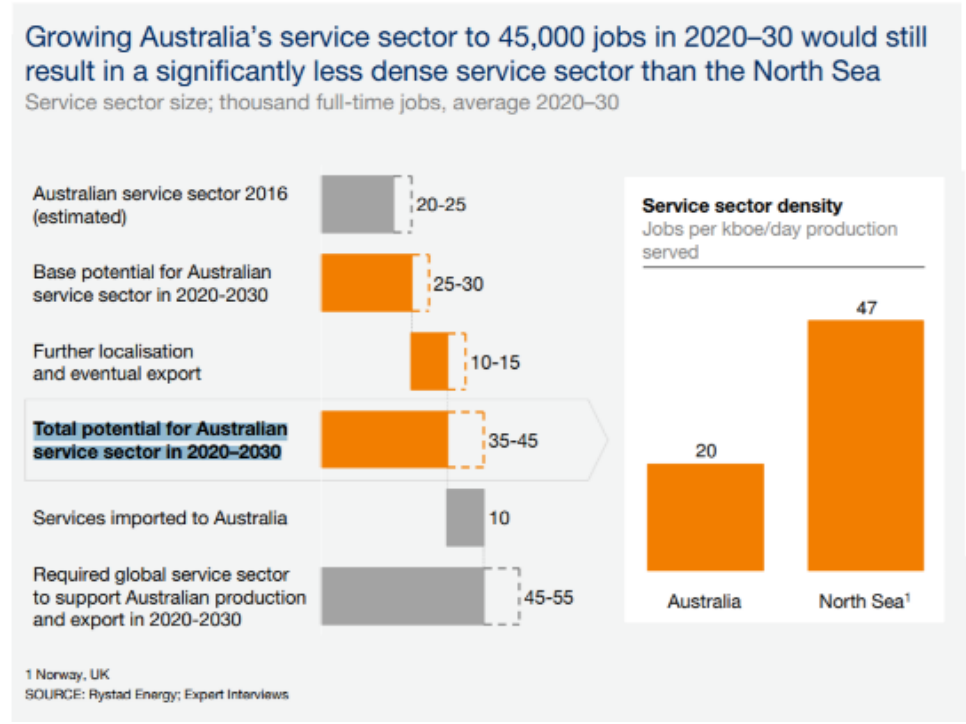

Fig. 6. LNG Employment Projection

Source: [25]

The growth of employment opportunities in the LNG sector in Australia is projected to grow to reach around 45,000 jobs. In the LNG operation phase, it is estimated that there are around 25,000 to 30,000 jobs, with gas demand continuing to increase every year- there is a potential for employment opportunities to reach 35,000 to 45,000 jobs [24]. The Australian Government will maximize its economic potential with the acceptance of several LNG projects. The decision to accept the LNG project will have an impact on the Australian 
economic sector, but the needs of the operation and the construction process also require workers from lower to upper levels; therefore, the Australian Government wants to ensure vast job opportunities for the Australian people

\section{Conclusion}

This research found that the Australian government is applying the Environmental Impact Statement, Environmental Authority based on the Environmental Protection, the Australia Government will ensure the LNG project will not harm and disrupt Australia's climate commitment and other environmental risks argued by the criticism and was the best decision for the Australian government to pursue their national interests in terms of the economy.

The Australian government's decision to accept the project's natural gas will bring great benefits, namely; an increase in the economy, an increase in the value of export commodities every year, creating large jobs in the 2 stages of construction and operation of natural gas projects, and of course increasing Australia's GDP. Australian government has prepared and assured all elements that this natural gas project will run safely with their climate commitments, by using the Environmental Authority mechanism and the Environmental Impact Statement mechanism. With this mechanism the Australian government is confident that their commitment to the Paris agreement will be achieved. Meanwhile, Natural gas in the 2017-2018 period contributed at least around A \$22,308 billion of the total Australian export commodities, moreover, the prospect of natural gas in the future is urgently needed as a substitute for energy from the use of coal.

In conclusion, the decision taken by the Australian government to accept the natural gas project will not oppose or interfere with Australia's climate commitment to the Paris Agreement. This decision brings the Australian government closer to their national desires and does not undermine global climate commitments.

\section{References}

1. A. J. Mcmichael, D. H. Campbell-Lendrum, C. F. Corvalán, K. L. Ebi, A. K. Githeko, J. D. Scheraga, and A. Woodward, Climate Change and Human Health RISKS AND RESPONSES Editors (2003).

2. R. W. Kates, T. M. Parris, and A. A. Leiserowitz, Environment (2005).

3. M. Yamin, A. Darmawan, N. Zayzda, \& M. Ash-Shafikh. Analisis Open Government dan e-Government di Indonesia Berdasarkan Kerangka Kerja SDGs: Studi Kasus Desa Melung, Kabupaten Banyumas. Jurnal Hubungan Internasional, 7, 133-143. (2018).

4. J. G. J. Olivier, K. M. Schure, and J. A. H. W. Peters, TRENDS IN GLOBAL CO 2 AND TOTAL GREENHOUSE GAS EMISSIONS Summary of the 2017 Report (2017).

5. F. Jotzo, Nat. Clim. Chang. (2012).

6. W. Lim, K. Choi, and I. Moon, Ind. Eng. Chem. Res. (2013).

7. L. Cox, (2019).

8. L. Cox, (2019).

9. T. Nace, L. Plante, and J. Browning, (2016).

10. Kilvert Nick, (2018).

11. A. Morton, (2019).

12. Tracker Climate Action, (2019). 
13. M. B. Miles and A. M. Huberman, A Sourceb. New Methods. California; SAGE Publ. Inc. (1984).

14. Fig Tree Capital Ventures LLC, (2019).

15. Statista, (2020).

16. NS Energy Staff, (2019).

17. A. Blume, (2014).

18. H. F. L. Williams, D. L. Havens, K. E. Banks, and D. J. Wachal, Environ. Geol. (2008).

19. Burton G. Allen, K. J. Nadelhoffer, and K. Presley, (2013).

20. T. Colborn, C. Kwiatkowski, K. Schultz, and M. Bachran, Hum. Ecol. Risk Assess. An Int. J. (2011).

21. Government Queensland, (2019).

22. Government Australia, Composition of Trade Australia 2018-19 (2018).

23. Allen Acil, (2018).

24. C. Y. Cheang, Rigzone (2013).

25. D. Dediu, M. Ellis, C. Heyning, P. Lambert, J. Segorbe, and A. Thain, Sustaining Impact from Australian LNG Operations (2016). 